\title{
Production of fish protein hydrolysates step by step: technological aspects, equipment used, major energy costs and methods of their minimizing
}

\author{
Inna Petrova $\cdot$ Ignat Tolstorebrov • Trygve Magne Eikevik
}

Received: 23 April 2018/Accepted: 22 September 2018/Published online: 27 September 2018

(C) The Author(s) 2018

\begin{abstract}
Nowadays, there is a growing interest on how to utilize fish materials remaining from the main production and considered as unappropriated for a direct human consumption. There are numbers of possible solutions to recover valuable nutrients from that matter and one of the most efficient is the production of fish protein hydrolysate. This article is devoted to overview existing information about the production of dried fish protein hydrolysates with a focus on dehydration process during production and equipment used for moisture removal. Drying step of the production is considered as the most energy demanding and, therefore, described in detail. Questions considering energy demands of the drying are highlighted in the article together with the proposals for the improvement of energy efficiency. This work also describes source of the raw material, the main steps of the technological scheme with the equipment used and valuable information on the intermediate state of fish protein hydrolysate between the process operations.
\end{abstract}

Keywords Drying $\cdot$ Fish protein hydrolysate $\cdot$ Fish by-products $\cdot$ Industrial drying systems

\author{
Abbreviations \\ $P \quad$ Pressure $(\mathrm{Pa})$ \\ $\mathrm{pH} \quad$ Logarithmic measure of hydrogen ion concentration (dimensionless) \\ $T$ Temperature $\left({ }^{\circ} \mathrm{C}\right)$
}

\section{Introduction}

Fish and marine products are one of the most used protein sources for human consumption. However, a big part of the catch is at its best utilized for production of cheap by-products such as fish flour, fish oil or animal feed or just wasted unused. At the same time, a growing amount of fishery and, consequently, of fishing wastes demands efficient solutions for their utilization since they are a good nutritional source, which is highly underestimated.

Fish protein hydrolysates (FPH) are a product made from fish or fish material by the method of protein hydrolysation (breakage of proteins from which fish tissues are constructed into smaller parts-peptides and

I. Petrova $(\bowtie) \cdot$ I. Tolstorebrov $\cdot$ T. M. Eikevik

Department of Energy and Process Engineering, Norwegian University of Science and Technology, 7491 Trondheim,

Norway

e-mail: inna.petrova@ntnu.no 
finally into amino acids). Thus, FPH is a mixture of broken proteins (Damodaran et al. 2008). FPH are reported to have a number of improved properties compared to the protein of origin which are namely improved functional properties (He et al. 2013; Kristinsson and Rasco 2000) and bioactive properties such as anti-oxidative (He et al. 2013; Chalamaiah et al. 2012; Sarmadi and Ismail 2010) or anti-hypertensive activities (He et al. 2013). Recently, FPH is also started to be used as cryoprotectants for frozen fish products (Jenkelunas and Li-Chan 2018).

FPH is produced in two forms: liquid and dried. Liquid FPH is a watering mixture of hydrolyzed proteins, which contains up to $90 \%$ of moisture. FPH in a liquid form is highly unstable for a long-term storage and, moreover, it is difficult to be transported. Thus, dried FPH is preferable due to a longer shelf-life, easier storage and transportation. Nevertheless, at the same time, the removal of such a big amount of water from liquid FPH is a difficult and costly task, which is one of the challenges of dried FPH production.

Thus, FPH has a huge potential use as a protein source for human consumption, but the step of dehydration demands a big energy supply and is, consequently, very costly. This article is devoted to highlight the main steps of moisture removal from FPH during the production, equipment used for the dehydration processes and possibilities to save or recover the used energy to cut energy costs.

\section{Technology and equipment of FPH production}

Availability of raw material

\section{Source of raw material}

The very first task of the implementation of FPH technology is the analysis of main fishing sources, which are the most abundant and, possibly, underutilized.

According to FAO (2016), China following by Indonesia, USA and Russian Federation were the leaders of marine fishery production. The countries holding leadership in aquaculture were China with 45.5 million tons, or more than $60 \%$ of global farmed fish production, following by India, Viet Nam, Bangladesh and Egypt (FAO 2016).

The main marine species in worldwide capture over years were the families of Gardidae (Alaska Pollock, Atlantic Cod, Blue Whiting, Pacific Cod), Engraulidae (Anchoveta, Japaneese Anchovy), Scombridae (Skipjack Tuna, Chub Mackerel, Yellowfish Tuna, Atlantic Mackerel, Seerfishes Nei), Clupeidae (Sardinellas Nei, Atlantic Herring, European Pilchard, Araucanian Herring, European Sprat, Pacific Herring), Carangidae (Scads Nei), Trichiuridae (Largehead Hairtail), Ommastrephidae (Humboldt Squid, Argentine Shortfin Squid), Nemipteridae (Threadfin Breams Nei), Scomberesocidae (Pacific Saury), Portunidae (Gazami Crab), Akiami Paste Shrimp (FAO 2016). Worldwide, the most important fish families farmed in aquaculture are Cyprinidae (Carp), Salmonidae (Salmon, Trout), Serranidae (Seabass), Acipenseridae (Sturgeon), Scophthalmidae (Turbot), Sparidae (Sea Bream), Mytilidae (Mussels), Ostreidae (Oysters) and some families of clams (European Comission 2012). Thus, due to the abundance of aforeisaid species in worldwide fishing production, an attention must be paid on better utilization of a big amount of by-products rested after their processing.

Global fish capture and aquacultural production in 2014 reached the values of 93.4 and 73.8 million tons, respectively, and only 146.3 million tons were used for human consumption (FAO 2016). From the amount used for human consumption, a big part was used as by-products or simply wasted. For example, the amount of non-edible fishing part, remaining from the filleting of salmon, generally reached $45 \%$ according to FAO (2017). According to Seafoodsource (2016), if all fish globally are processed and all the by-products collected, the amount of 36 million tons left from the main fish processing would be available as raw material for further treatment. However, the authors of Seafoodsource (2016) claimed that only 5.7 million tons of by-products are currently processed and as much as 11.7 million tons are not collecting from processing plants for further utilization.

More precise distribution of fish by-products and unutilized wastes was published by Richardsen et al. (2015) for the Norwegian fishery sector. According to the authors, the main fishery groups produced in Norway in 2015 were aquaculture, pelagic and white fish production from which as much as $43 \%, 12 \%$ and $29 \%$ correspondingly were rested. The rests from pelagic sector were almost totally utilized for fish flour and 
other fish products. The amount of unutilized fishing rests from aquaculture facilities was moderate ( $9 \%$ of the total quantity) and the biggest amount was observed for the white fish industry (52\% of the total quantity).

Thus, underutilized and underestimated fishing rests from the main production can be processed to get FPH, which can increase efficiency of fish processing by redirection of the by-products for human consumption. This is both more profitable and environmentally friendly than using fishing resting material for fish meal. In the case of FPH, the fishing industry avoids a two-stage circle of fishing rests consumption to feed animals, which will be consumed by humans and allows delivering a food resource straight to the final consumer.

In spite of economic benefits of FPH production, the main hindrance of complete by-product utilization is a logistic issue. There is a need for quick transportation of by-products in order to avoid spoilage. However, due to a general lack of well-organized model of collecting, storage and transportation, further utilization of fish by-products is complicated and available fish source may be even lost as wastes. An example of successful collaboration between fish processing plants and by-product utilization facilities is Iceland Ocean Cluster, which is made up of nearly 70 companies located in a common building of around 9000 square meters (SeaFoodSource 2016). Such models if realized globally may help better utilization of fish by-products due to easy transportation and high speed of fishing rest secondary processing.

\section{Type of raw materials}

Raw materials for FPH production can be both fish and fish left-overs. Since the usage of whole fish or only fish by-products may influence the processing, Table 1 is designated to roughly compare the chemical composition of whole fish and fish by-products exemplified by fish heads and backbones (salmon (FAO 2007; Ytrestøyl et al. 2014) and cod (Bikov et al. 1998) are taken for the comparison).

As it is seen from the table, some fluctuations and differences in the chemical content between different types of fish raw matter are possible due to the type of raw matter; however, similar fluctuations can be observed since seasoning, etc. In all cases, raw materials should be carefully evaluated at technological line in order to provide effective recovery of protein fraction. Further in the article, the terms of raw material will be corresponded to any type of raw materials, generally used for FPH production, including both whole fish and fish by-products.

\section{Technological scheme}

A principal technological scheme of FPH manufacturing is presented in Fig. 1. The process starts from a takeover of raw materials. Water, chemicals or enzymes are added to minced raw material to obtain chemical (acid or alkali) or enzymatic hydrolysis correspondingly. After a certain time, when a certain desired extent of hydrolysis is achieved, there is a need to stop the hydrolysation process by chemical or thermal treatments according to the hydrolysis method. After termination of hydrolysis, the protein mixture is delivered to solid

Table 1 Chemical composition of by-products and whole fish for salmon and cod

\begin{tabular}{llrrr}
\hline Nutrients & \multicolumn{2}{l}{ By-products } & & Whole body \\
\cline { 2 - 5 } & Heads & Backbones & Average & \\
\hline Salmon & & & & 58.8 \\
Moisture & 66 & 64.3 & 65.1 & 21.3 \\
Lipids & 16.7 & 15.2 & 16.0 & 17.5 \\
Proteins & 11.3 & 14.1 & 12.7 & 2.4 \\
Ash & 6.0 & 6.4 & 6.2 & 75.3 \\
Cod & & & & 5.7 \\
Moisture & 79.5 & 75.0 & 77.3 & 13.0 \\
Lipids & 0.3 & 0.4 & 0.4 & 14.6 \\
Proteins & 13.9 & 15.2 & 7.3 & 3.4 \\
Ash & 5.6 & 9.0 & \\
\hline
\end{tabular}




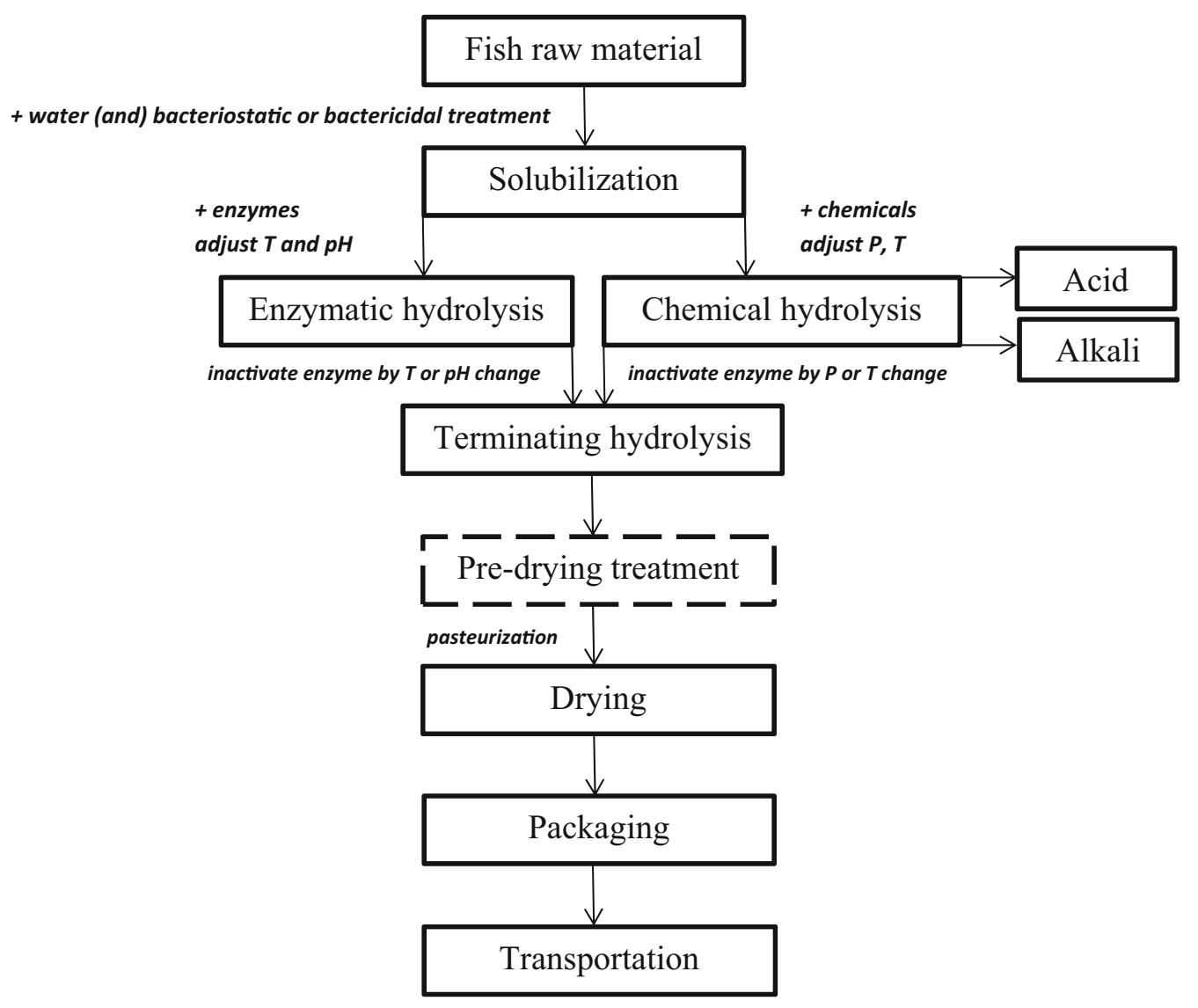

Fig. 1 Principal scheme of FPH production

separation where liquid part is separated from the solids. Then, a heating procedure can be applied if desired to treat the fish protein hydrolysate by temperature to reduce microbial activity (pasteurization). The term of pasteurization in FPH technology is different from that in dairy production due to higher temperatures used. In some cases when the final product has to have a certain quality, for example, to be used for biochemical purposes as a microbiological media, removal of salt can be provided. After the protein mixture can be concentrated to remove some water before the drying procedure. It makes the process of drying more efficient due to the decreased quantity of water to be removed. However, at the same time, preliminary water removal by concentration needs additional equipment and energy to provide the dehydration process, thus, the need of such an extra treatment is decided by a producer for each certain case. Liquid FPH slurry is then delivered for drying and dried FPH is sent for packaging and transportation. FPH are normally stored at $4{ }^{\circ} \mathrm{C}$ or lower, in some cases with vacuum packaging mainly to prevent lipid oxidation (He et al. 2013).

Hydrolysation

Hydrolysation of proteins can be generally provided by chemical (acid or alkali treatment) or by biochemical methods. Biochemical hydrolysis is provided by proteolytic enzymes, which are already present in fish tissues (autolysis) or by premixing of commercial enzymes in order to accelerate the process (enzymatic hydrolysis). Some literature on novel methods of fish protein hydrolysis is nowadays available in scientific publications, for example, the work of Hoeling and Volkov (2015) describing the method of hydrothermal extraction. However, such methods need to be well evaluated before they can be used at an industrial scale. Other extraction methods than those mentioned above do not hydrolyze proteins, but are used for protein concentration by removal of a part of water and/or fat (concentration or isolation of protein fraction) (Kristinsson and Rasco 2000). 
All methods of hydrolysation are held with one final purpose-extraction of protein part by the deformation of fish proteins into smaller parts (peptides and amino acids) and their further separation. The peptides and amino acids, formed by protein degradation, have smaller molecular mass and can be absorbed by digesting system faster than proteins (Di Pasquale 2008). It is a particularly important property for those, whose organism is weakened by a disease or who need a quick nutritional supply (for examples, sportsmen).

Fish material is solubilized with water by the solid content of 8-20\% (Pasupuleti and Braun 2010). Generally, water and fish material are mixed as $1: 1$. However, there is also a possibility of hydrolysation process without water addition (Himonides et al. 2011; Rebeca et al. 1991). Producers should evaluate the amount of added water for the hydrolysation step in order to provide a suitable extent of the protein breakdown and at the same time avoid extra costs for dehydration of unnecessary water fraction from FPH on the step of drying.

Hydrolysation is generally held in metallic tanks (hydrolysators), which are in most cases constructed and installed by producers of FPH by themselves. The hydrolysators should be constructed so, as heat is supplied to the tube shell of the tanks and, desirably, an agitation blade is installed into the tank to mix the hydrolysate mixture for uniform temperature and chemical distribution. The amount of heat provided as well as the temperatures used for the hydrolysation depends on the type of hydrolysis, nature of raw material, used chemicals and other factors.

During the treatment, one needs to know how the degradation of proteins should be extended. To evaluate the extent of hydrolysation and follow its kinetics, the parameter named "degree of hydrolysys" (DH) is used. DH can be measured by a range of methods, which is overviewed by Kristinsson and Rasco (2000) and expressed as the ratio of broken peptide bonds to the total peptide bonds in the mixture per unit weight (Eq. 1):

$$
\mathrm{DH}=\frac{P_{\mathrm{br}}}{P_{\mathrm{tot}}} \cdot 100 \%
$$

where DH is the degree of hydrolysis in percent; $P_{\mathrm{br}}$ is the numbers of broken peptide bonds; $P_{\text {tot }}$ is the total number of peptide bonds in the mixture.

DH is correlated with such functional properties of final FPH as solubility, emulsifying capability, foaming ability, fat absorption ability, and with such an important sensory property as bitterness (He et al. 2013; Kristinsson 1998; Kristensson and Rasco 2010; Kuehler and Stine 1974; Quaglia and Orban 1987, 1990). A number of researches showed that bitterness of protein fraction increases with the decrease in peptide size (Aliani and Eskin 2017; Aubes-Dufau et al. 1995). Slizyte et al. (2010) claimed that the presence of di- and tripeptides, which are the main protein fragments of FPH (Manninen 2004), will give far more bitter taste compared with FPH which mostly consists of larger protein fragments. However, Slizyte et al. (2010) also noticed that with further degradation of peptides into amino acids, the bitterness also decreases. In such a case, the process of hydrolysis shall be well adjusted to avoid undesirable sensory properties of final FPH and, therefore, to control not only $\mathrm{DH}$, but also the obtained length of protein fragments. Chemical and enzymatic hydrolysation techniques allow a different amount of process control, which is extremely important for the choice of hydrolysation method.

\section{Chemical hydrolysation}

Chemical hydrolysis is provided by either acid or alkali. It is achieved by cleaving the bonds between different peptide groups in the protein sequence by chemical agents. Since this process is held at extreme working parameters (high concentration of acid or alkali, high temperature), the process of hydrolysis in this case is almost uncontrollable. As a result, the nutritional and functional properties of final FPH are reduced (Loffler 1986; Webster et al. 1982) and also varied due to the lack of control and traceability (Blenford 1994; Kristinsson and Rasco 2000; Skanderby 1994). Thus, FPH produced by chemical hydrolysis has a very limited spectrum of utilization.

Acid hydrolysation Acid hydrolysis is more widespread than that by alkali. Typically, fish is involved reacting with hydrochloric acid, but there are plenty of technologies involving sulfuric acid. High temperature and pressure of solution (121-138 ${ }^{\circ} \mathrm{C}$ and $220-310 \mathrm{mPa}$ correspondingly) are held during several hours 
(typically 2-8) in order to achieve a certain DH (Pasupuleti and Braun 2010). The mixture is then neutralized to $\mathrm{pH}$ 6.0-7.0 and delivered for further dehydration (Kristinsson and Rasco 2000). The process of acid hydrolysation has several drawbacks such as high $\mathrm{NaCl}$ content which makes the final FPH inappropriate for some food and especially biochemical applications (Kristinsson and Rasco 2000; Pasupuleti and Braun 2010) or the destruction of tryptophan which is an essential amino acid (Jaswal 1990; Pasupuleti and Braun 2010).

Alkali hydrolysation Alkali hydrolysis is held at less elevated temperatures (typically $27-54{ }^{\circ} \mathrm{C}$ ) in the presence of such alkaline agents as calcium, sodium or potassium hydroxide during several hours until the desired degree of hydrolysis is reached (Pasupuleti and Braun 2010). The use of alkali reactants, mainly sodium hydroxide, generally results in reduced functionality and nutritive value of final FPH. Moreover, a range of substances, which are not absorbed or even toxic for human organism, can be created during alkali hydrolysis (Kinsella and Melachouris 1976; Kristinsson and Rasco 2000; Lahl and Braun 1994; Linder et al. 1995). A number of amino acids as serine and threonine are destroyed during alkaline hydrolysis; however, tryptophan remains intact contrary to the acid hydrolysis (Pasupuleti and Braun 2010). Despite described drawbacks, limited alkali hydrolysis is used in the fish processing industry to recover a range of proteins from fish material and fish protein concentrates in order to hydrolyze a valuable protein fraction and, thus, improve the functionality (Kristinsson and Rasco 2000; Sikorski and Naczk 1981; Tannenbaum et al. 1970a, b).

\section{Enzymatic hydrolysation}

In this review, the attention is paid to the treatment when a specific enzyme or a mixture of enzymes is premixed to the hydrolysated slurry. This is more convenient and controllable method than that with autolytic enzymes due to a high variation in optimal conditions for each of enzyme in the autolytic enzymatic mixture and their variation influenced by species, season, gender, age, etc. (Kristinsson and Rasco 2000).

Enzymatic hydrolysis is carried out from one to several hours at mild conditions: slightly elevated temperatures (generally around $35-65^{\circ} \mathrm{C}$ ) and a certain $\mathrm{pH}$ according to the optimal requirements of the used enzymatic systems: alkali (for example, alcalase), neutral (papain, bromelain, alcalase, neutrase and flavourzyme) or acid (pepsins). Used for FPH production enzymes are of animal (pepsins), plant (papain, bromelain) or microbial origin (alcalase, neutrase, flavourzyme). Enzymes of microbial origin are considered as having greater $\mathrm{pH}$ and temperature stability (He et al. 2013). The application of enzymes allows obtaining a high-quality FPH avoiding such drawbacks as the developing of undesirable products of racemization as in a case of acid and alkali hydrolysis (Gonzalez-Tello et al. 1994). In addition, enzymatic hydrolysis allows a controllable distraction of a certain type of proteins by a certain chain cleavage due to enzymes' specificity with an easy process of enzyme inactivation after a certain DH is achieved (Pasupuleti and Braun 2010). The inactivation of enzymatic hydrolysis is typically accomplished by the elevated temperatures of around 75-100 ${ }^{\circ} \mathrm{C}$ applied for 5-30 min (Kristinsson and Rasco 2000).

Despite the aforesaid benefits, there are certain limitations when enzymatic hydrolysis is utilized. Among them are high costs of industrial enzymes, low yield, the need of a special treatment in order to deactivate the enzymatic hydrolysis, the difficulties of process control to obtain a certain molecular mass of the products of protein degradation and the bitterness of final FPH (He et al. 2013; Kristinsson and Rasco 2000). However, recent researches with different enzymes used for FPH production revealed the mixture of papain and bromelain as a very promising solution for avoiding bitterness at the production of FPH from herring (Slizyte et al. 2010). Table 2 shows a rough comparison of bitterness between different enzymatic systems based on the data published by Slizyte et al. (2010) for the production of FPH from herring. Exact values of relative bitterness as well as materials and methods of its evaluation can be found in the rapport of Slizyte et al. (2010). The values in the table are derived from the Fig. 19 (page 23) published by Slizyte et al. (2010).

Moreover, the resulting FPH has both an acceptable DH and yield (Slizyte et al. 2010. 
Table 2 Comparison of bitterness for different enzymatic systems

\begin{tabular}{lc}
\hline Enzymatic system & Relative bitterness \\
\hline Papain and bromelain & 3.4 \\
Autolytic enzymes & 3.7 \\
Flavourzyme & 4.1 \\
Bromelain & 4.6 \\
Protamex & 4.7 \\
Papain & 4.8 \\
Promod & 5.1 \\
Alcalase & 5.5 \\
\hline
\end{tabular}

\section{Dehydration of FPH}

\section{Purification}

To utilize hydrolyzed proteins as FPH, there is a need to separate protein fraction mainly from insoluble and fat fractions before the further dehydration. It is possible to be accomplished by a range of methods, mostly by centrifugation and plate and frame filtration.

In more advanced technologies, when a certain quality of final FPH is needed, the filtration of small chemical particles from the hydrolysation mixture can be provided (microfiltration, ultrafiltration and nanofiltration from bigger to smaller particle separation correspondingly) (Pasupuleti and Braun 2010). In some cases, electro-membrane filtration is also utilized for FPH fractionation, for example, in order to fractionate active peptides from complex hydrolysates (Suwal et al. 2018).

The temperature of purification mainly depends on the temperature of the delivered protein mixture and is not changed especially during the purification process by an additional heat supply.

After the separation of protein part, the mixture is generally pasteurized at high temperatures in order to eliminate possible microbial contamination. Pasteurization can be accomplished one or several times during the production line of FPH according to the technology used by a certain producer (Pasupuleti and Braun 2010).

\section{Centrifugation}

Generally, the process of centrifuging is used in order to separate the hydrolyzed mixture on several fractions for further recovery of the protein part.

Centrifuging is provided by different centrifuges, which are classified according to a certain property such as their intended use, continuous/batch operation, construction, speed, etc. A common future of all existed centrifuges is that the main element of the machine is a rotor which rotates at high velocities generally up to $20,000 \mathrm{~g}$ (where $g$ is the acceleration of gravity) if for industrial applications. The simplest principle scheme of the centrifuge is shown in Fig. 2, but can be modified according to the type of centrifugation.

Centrifugation in the processing of FPH can be done in one or several steps according to the desired quality of FPH. The centrifugation of mixture at $4000 \mathrm{~g}$ for at least $20 \mathrm{~min}$ basically separates the mixture into three fractions: the sludge and solid layer at the bottom, the protein hydrolysate solution in the middle and the fish oil layer on the top (He et al. 2013). Cui (1996) reported more detailed fractionation of the mixture on sludge in the bottom, aqueous layer in the middle, lipid-protein fraction between aqueous layer and sludge, aqueous and oil layers and oil layer on the top; visualized picture of these layers can be found in the paper (Kristinsson and Rasco 2000).

The solids are separated from the liquid protein mixture mainly in order to purify the FPH from insolubles while the fish oil fraction is removed to avoid undesirable fat oxidation processes in the final FPH. The desirable fat content of final FPH is to be $0.5 \%$ (He et al. 2013; Spinelli et al. 1972) in order to avoid the influence of lipid changes on the quality of final FPH during shelf-life. However, Chalamaiah et al. (2012) 


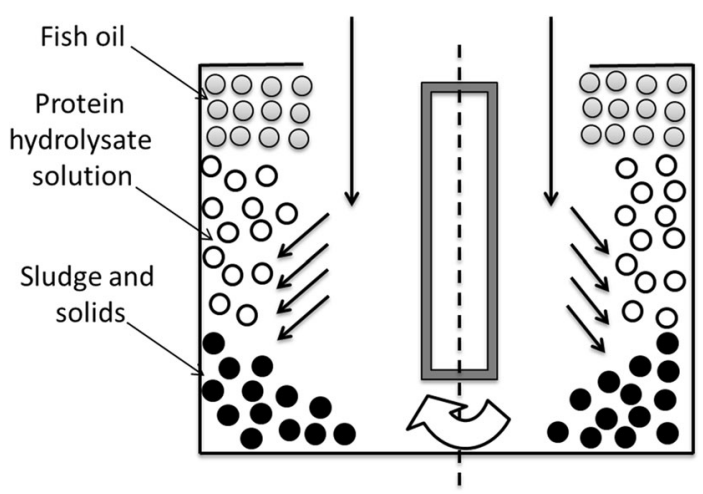

Fig. 2 Principal scheme of simplest centrifuge

overviewed a number of research works where the fat content reported to be at least less than 5\% and even a few studies where the fat content was claimed to be less than $10 \%$.

\section{Plate and frame filtration}

Plate and frame filtration presses working at the pressure of approximately $410-550 \mathrm{mPa}$ are basic operation units, used by industrial FPH producers in order to purify protein fraction of hydrolysates from different impurities. As for investigations considering such a filtration for any studies with FPH, the information is very limited by a few publications (Chakraborty and Madhavan 1977; Loosen et al. 1994). It explains by the fact that plate and frame filtration is rather a technological step at a large production than a matter of investigation.

A simplest sketch of such a press is shown in Fig. 3. Plates equipped by filters consisted of special cloth material are constructed into a filter frame. Filter aid is applied on the surface of the filters in order to bind different impurities of the mixture and hold them into the filter cloth, or sometimes simply premixed to the mixture before filtration. The filtrated mixture enters the press and goes through the paths between the filter plates leaving impurities on the surface of the filters. Process recycles until a certain purity of the mixture is achieved.

The nature of impurities, which can be collected by the filters, depends on the nature of filter aid. Special attention must be paid on the nature of filter aid since it can also remove some desirable compounds from FPH slurry, such as some peptides and amino acids (Silvestre et al. 2009). Filter aids are generally made of porous

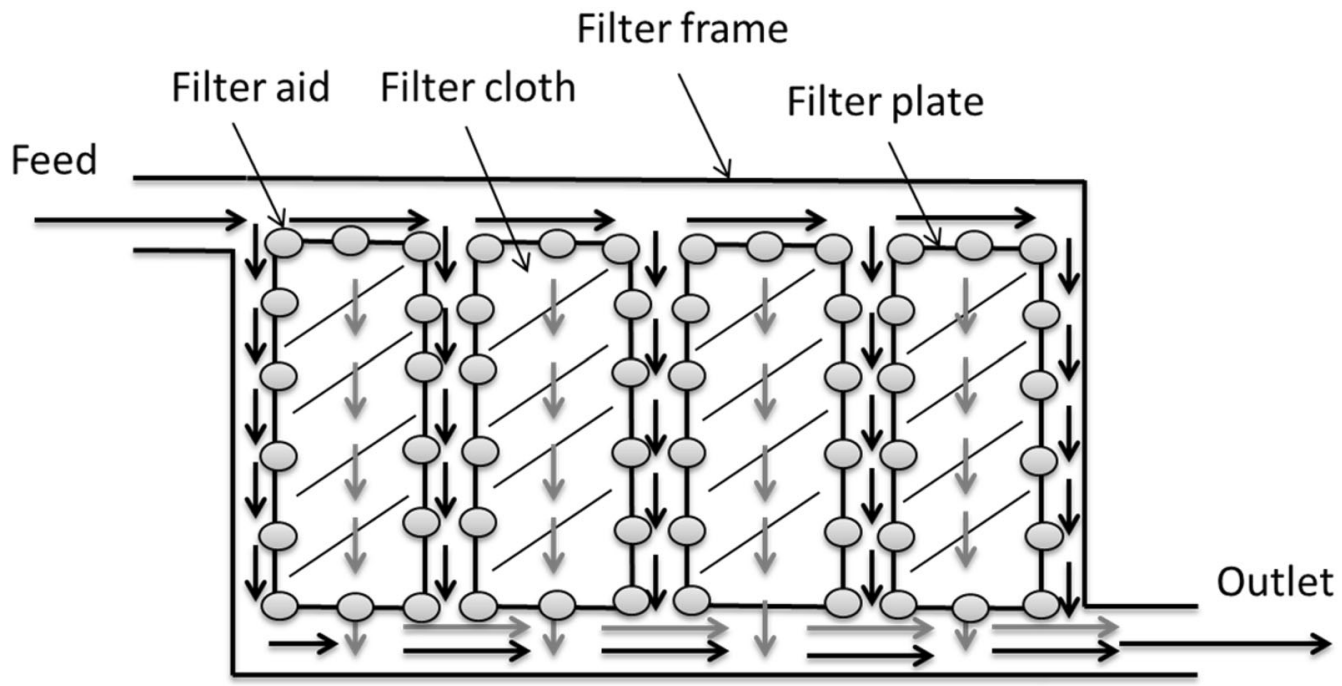

Fig. 3 Principal scheme of plate and frame filter press 
inert materials such as silica-based rocks (diatomaceous earth), wood cellulose, perlite, etc. Filter aids for FPH usually consist of volcanic rocks or diatomaceous earth, but if the purpose is discoloration, or removing of hazard components, charcoal powder can be applied (Chae et al. 1998; John 1993).

The capabilities and operation time of the press are depended on the amount of solids in the filtrated mixture. Roughly, the capabilities are ranged between approximately 2-3 L per minute according to the initial solid content, which is estimated to be between 1 and 10\% from the total amount (Kristinsson and Rasco 2000; Mine Engineer Product Manual 2009).

Micro-, ultra- and nano-filtration After plate and frame filtration, when bigger particles are caught by the filters, the protein mixture can be delivered to membrane filters for careful fractionation or concentration of FPH mixture. Membrane filtration is a useful tool for obtaining certain groups of peptides utilized for different purposes (for example, bioactive peptides) (Abejón et al. 2018).

Membrane filters are micro-, ultra- and nano-filters according to the aimed particle size: down to approximately 100, 10 and $1 \mathrm{~nm}$ correspondingly (Fig. 4). Peptides in FPH slurry can be also separated by membranes based on their charge and hydrophobicity characteristics (Abejón et al. 2018). Membranes are made of nylon, polyethersulfone, polyvinylidene difluoride, polytetrafluoroethylene, mixed cellulose ester, cellulose acetate, polypropylene and other material (Microlab Scientific 2018).

Microfiltration is not a popular method utilized by researchers for the filtration of FPH, probably, due to the aimed particles to be plugged (the most bioactive peptides) are usually with a smaller size ( $\leq 4 \mathrm{kDa}$ ) (Abejón et al. 2018; Saidi et al. 2014; Vandanjon et al. 2009), than microfilters can retain. The filtration range of microfiltration is generally less than $100 \mathrm{kDa}$, which is far bigger than the aimed peptide size. By contrast, ultra- and nano-filtration is recently investigated in a large number of research articles on FPH (Abejón et al. 2016, 2018; Bourseau et al. 2009; Roslan et al. 2018; Saidi et al. 2014; Vandanjon et al. 2009) or was used as a filtration tool in other investigations of FPH (Abdelhedi et al. 2018; Halim et al. 2018).

Ultrafiltration is used in most studies for fractionation or separation, while nano-filtration is utilized for peptide or amino acid concentration (Saidi et al. 2014).

Coupling ultra- and nano-filters in various types of cascades is used by many researchers for better efficiency of the filtration process. (Abejón et al. 2016, 2018; Bourseau et al. 2009; Saidi et al. 2014; Vandanjon et al. 2009).

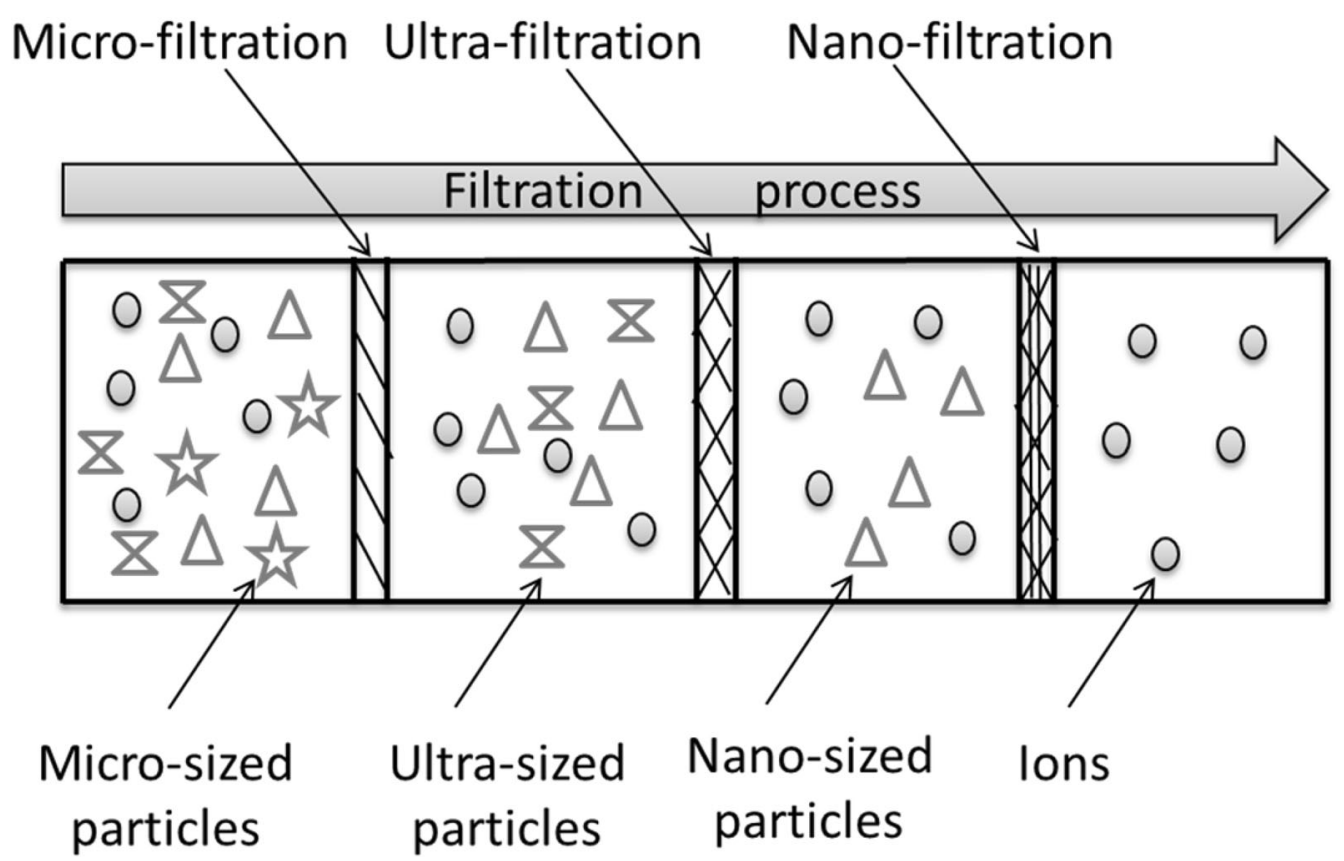

Fig. 4 Principal scheme of micro-, ultra- and nano-filtration 
It is important to adjust the membrane to the desirable size of the particles to be separated in order to obtain an effective filtration process and avoid free flow of the aimed solids, which are too small through the membrane. At the same time, when deciding about the pore size, it is important to remember that all particles of the used size pore would be plugged. For example, if the aim is to remove endotoxins, the used membrane can cut off also a great amount of peptides with the same size (Pasupuleti and Braun 2010). Thus, the "golden mean" between the filtration and protein yield for FPH production should be found for a certain case.

When membrane separation is utilized, the process should be well adjusted to maximize the product purity and the process yield: pore size of membranes, pressure, flow rates, $\mathrm{pH}$, salt concentration of the solution and other essential parameters should be considered. At the same time, total costs and environmental consideration must be also taken into account; in this case, water recovery may be a useful solution (Abejón et al. 2018). However, the simultaneous concurrence of high purity and yield values is not possible even considering all important factors, which influence the process of filtration (Abejón et al. 2016).

The effectiveness of peptide fractionation in FPH production can be troubled by disposition and, eventually, clogging of solid parts on membrane surface due to protein-protein or protein-membrane interaction. These phenomena are known as membrane fouling and are considered as a major problem leading to poor FPH separation and low peptide yield (Roslan et al. 2018). Membrane fouling can be controlled by various methods: applying external electric, magnetic or ultrasonic field, adjusting pH (Roslan et al. 2018; Zhu et al. 2017) or applying freshwater streams in order to control protein content in inlet and outlet streams of membrane modules (Abejón et al. 2018).

\section{Concentration}

Concentration is used to reduce water content in the protein mixtures before drying and, thus, reduce the energy costs of the drying step. Concentrators are apparatuses where the liquid solution to be concentrated goes through a large specific surface which is heated up. Thus, going through the heated surfaces of concentrators, moisture is evaporated and removed to the atmosphere by vapor.

The temperatures used for evaporation and evaporation rate vary for different FPH depending on the composition of the mixture and other properties influencing the boiling point such as DH, protein source or the choice of enzyme. At the same time, the productivity of the devices depends on their size and capability and can achieve 150 t/hour (GEA 2018).

Depending on the capabilities of the used concentrators and the allowable solid content in the mixture for further safe operation of dryers, the protein hydrolysate solution can be concentrated up to $50 \%$ solids (Pasupuleti and Braun 2010). Mostly used modifications of concentrators are falling and rising film evaporators which differ from each other by the way of product supply and, correspondingly, by the construction.

After evaporation, some producers add a final pasteurization before the concentrate is delivered to be dried.

Falling film evaporators A simple sketch of a falling film evaporator is shown in Fig. 5. The protein mixture starts to boil at the top of the apparatus. Then, it goes from the top of the apparatus through the heated tubes with help of gravitational force towards the bottom and the output valve. The surplus of moisture is removed through a special vapor valve.

Rising film evaporators In a rising film evaporator, the protein mixture, in contrast to a falling film evaporator, goes from the bottom to the top of the apparatus through heated tubes (Fig. 6). The mixture reaches the boiling temperature at the bottom and the liquid and vapor parts flow together upward towards the top against the gravitational force. The concurrent movement of liquid-vapor mixture upward creates a high degree of turbulence, which gives better efficiency of the evaporation process (NPTEL 2013). The surplus of moisture is then evaporated and removed through a special vapor valve.

\section{Drying}

Drying of FPH is a process, which allows ensuring a stable shelf-life of final FPH by water content decrease and making the transportation of FPH easier due to the reduced mass and volume of the final product. 


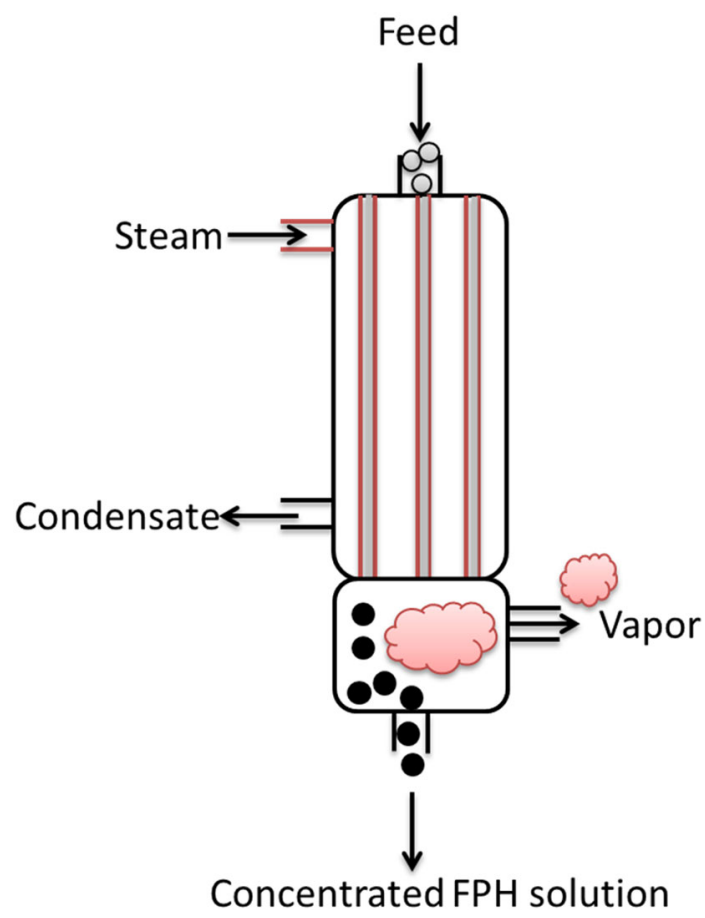

Fig. 5 Principal scheme of falling film evaporator

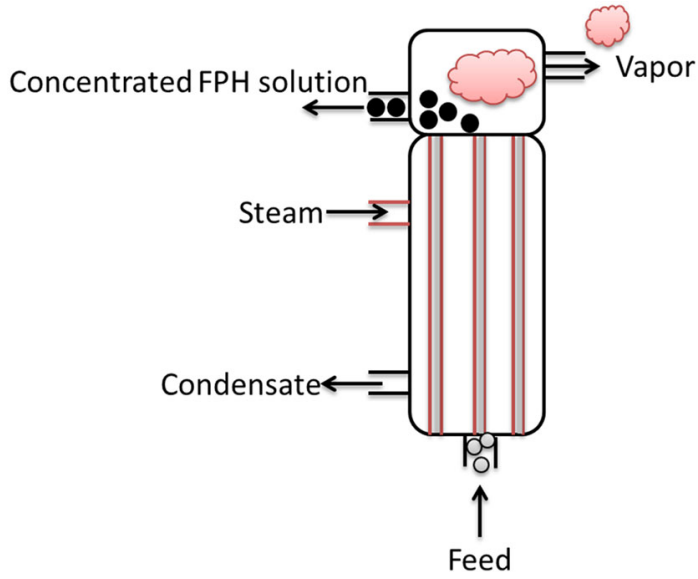

Fig. 6 Principal scheme of rising film evaporator

The drying process of FPH is usually accomplished by a limited number of drying apparatus: they are typically spray dryers which provide convectional drying, and vacuum freeze dryers and roller drum dryers which utilize contact heat supply. From the experience, the authors suggest convection spray dryers as the most used drying systems at large scale in FPH production due to a satisfactory productivity, reasonable quality of the final FPH and a relative easiness of operation. The term "spray dryer" is used in this article to describe convectional spray dryers; the authors do not devote the work to spray drying using radiation or mixed heat transfer.

The choice of drying method at laboratory scale generally depends on the availability of drying equipment at a certain laboratory and not depends on the purposes of the research or the properties of studied FPH. Thus, it is difficult to classify the used equipment according to the studied properties of FPH. Generally, the mostly used drying equipment for research purposes is spray and freeze dryers. 
Spray drying A typical spray dryer is a drying apparatus, which consists of a cylindrical tube with a feeding system at the top and an outlet configuration normally equipped by a separator of dried FPH and a filter to clean the output air (Fig. 7). The design of the drying tube typically depends on rheological properties of droplets, an used droplet size, residence time of droplets in a drying chamber and desired moisture content of the final dried FPH. Rheological properties of dried droplets, which are important in a sense of spray drying, are solid content, density, surface tension and viscosity. The question of a spray dryer design, which is of interest, is uniform heat delivery to all droplets and efficient solid separation (Wisniewski 2015).

Liquid FPH is supplied to the feed system and sprayed into the tube chamber by a special deviceatomizer. Atomizer can be made by a different configuration according to the dryer construction, the rheological properties of liquid and desired size of droplets.

Industrial spray dryers typically have rotary disk atomizers, or single fluid high pressure swirl nozzles. In rotary atomizers (Fig. 8a), liquid is centrifugally accelerated to high velocity before discharging into the hot gas in a co-current mode. Rotary atomizers are suitable for a large number of products. In a case with high pressure nozzles, a high pressure is applied to the liquid in the atomizer before forcing it out into the drying chamber in a co-current (Fig. 8b) or fountain mode (Fig. 8c). Pressure nozzles are typically applied for coarser particles than other atomizers (GEA Process Engineering A/S 2016).

Smaller spray drying apparatus may be equipped by swirl nozzles, typically two-fluid swirl nozzles, where the droplets are sprayed by a high velocity compressed gas jet. These atomizers can be constructed with cocurrent or fountain mode of droplet discharging. Small laboratory spray dryers generally have multi-fluid nozzles or ultrasonic spray nozzles (Wisniewski 2015).

Depending on the type of atomizer, the liquid is mixed with the hot drying gas and flows into the drying chamber towards the outlet. When liquid FPH is supplied into the drying chamber and sprayed by the atomizer, the fine particles of liquid start immediately to interact with hot inert drying gas, which is delivered from the heating system. Simultaneous heat and mass transfer occurs while heat is supplied to the droplets from the drying agent by convection. The temperature of the droplets is rapidly increased up to the wet bulb temperature and the moisture from the particles starts to evaporate with a certain almost constant rate. At the same time, the drying gas temperature decreases. This period is considered as a first stage of spray drying;

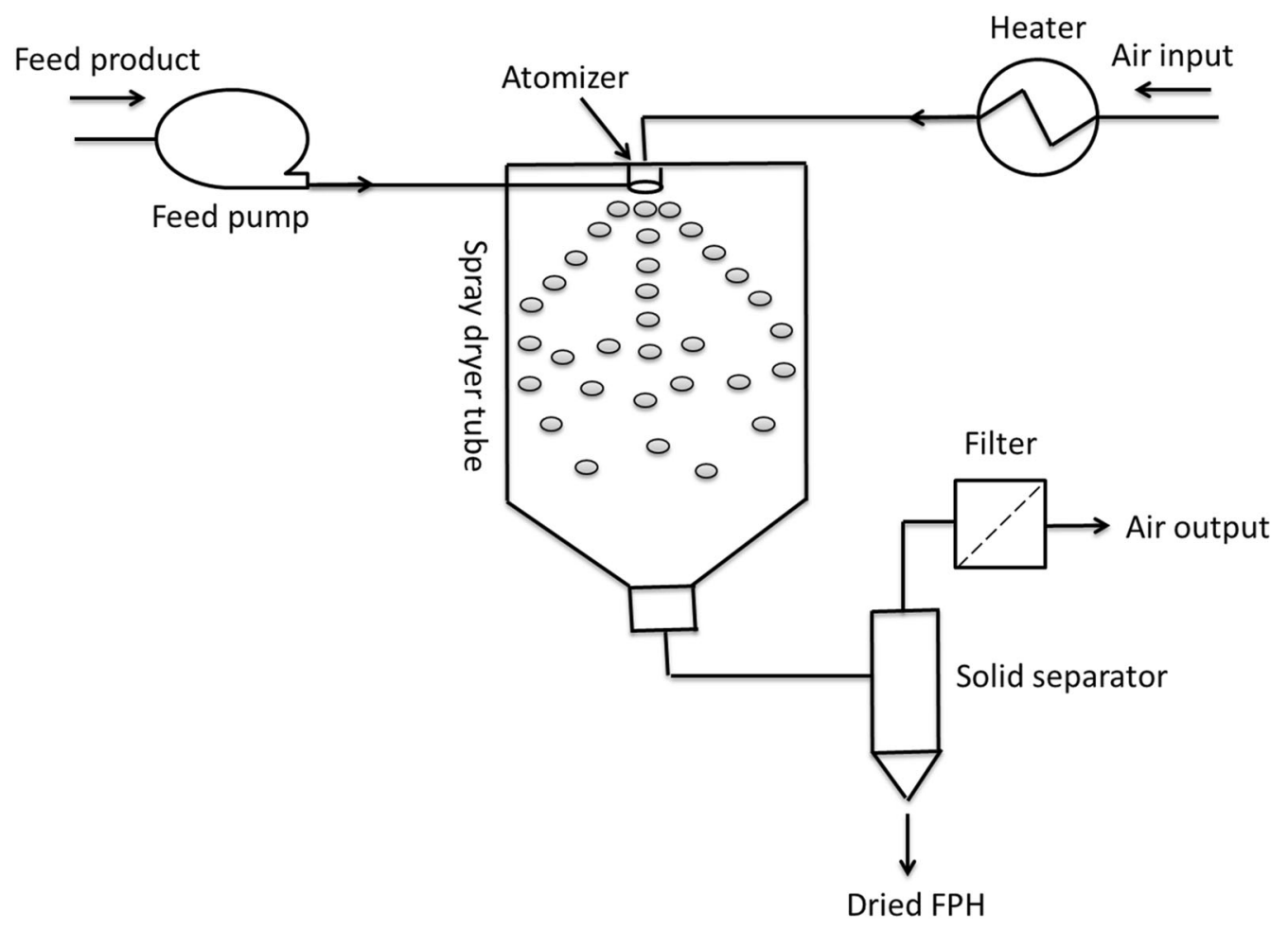

Fig. 7 Principal scheme of spray dryer 


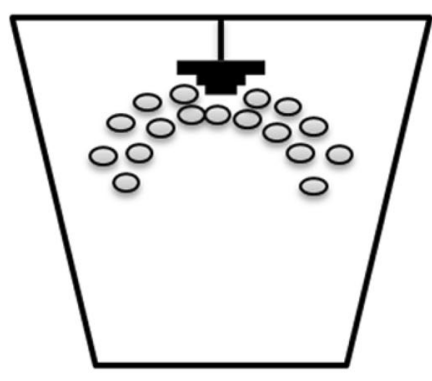

a
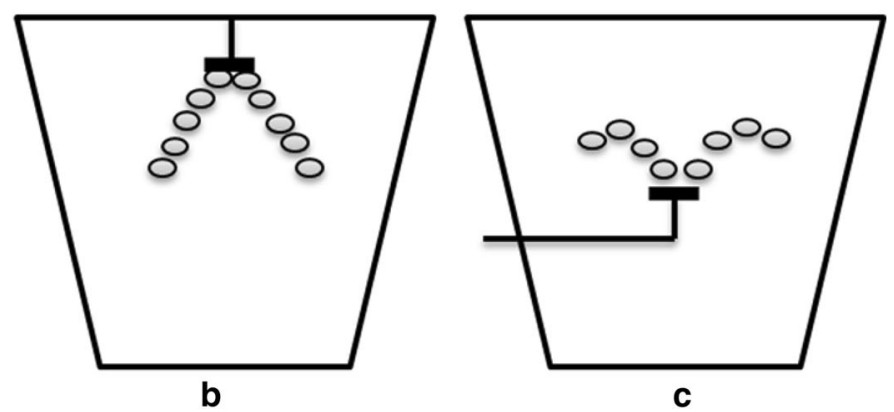

Fig. 8 Principal sketch of atomizer configuration: a Rotary atomizer. b Two-fluid nozzle atomizer with co-current mode. c Pressure nozzle atomizer with fountain mode

most water is removed during this stage. During the second stage, the temperature of the particles rises toward the air temperature at the outlet of the drying chamber (Huang et al. 2017, Wisniewski 2015). The final dried FPH is collected from the solid separator, which is mounted at the chamber's outlet and delivered to be packed and further transported.

Spray drying of FPH normally held at high temperatures in a diapason $150-220^{\circ} \mathrm{C}$. Exact temperature modes and residence time into the drying chamber are dependent on the rheological and sensitivity properties of the dried mixture and the desired moisture content in the final FPH. Higher inlet temperatures give higher evaporation rate, but can be damaging to the quality and bioactivities of final FPH. Thus, temperature mode is carefully adjusted in each case according to the purposes of production. Resistance time in spray dryer generally varies between 5 and 100 s (Masters 1991). Dried product rate of spray dryers is depended mainly on the working volume and capacity, rheological properties of solution, flow rate and a type of installed atomizer. Laboratory spray dryers such as model GA 32 (Yamato Scientific Co., Ltd.) have maximal water evaporation rate of $1.3 \mathrm{~kg}_{\text {water }} / \mathrm{h}$, while industrial spray dryers can evaporate much more than $1000 \mathrm{~kg}$ water $/ \mathrm{h}$.

Spray drying is a popular method used at different productions over years due to its high productivity. However, for research purposes its use is limited by the availability at a certain research laboratory, where freeze dryers are rather available. Nevertheless, some research laboratories are equipped by spray driers and a number of research works on FPH have been published. Thus, Abdul-Hamid et al. (2002) studied nutritional quality of spray-dried FPH from Black Tilapia. Recently, Morales-Medina et al. (2016) used spray drying for the microencapsulation of fish oil by FPH made from sardine and horse mackerel. The new research of Silveira Alvares et al. (2018) used spray-dried FPH for the examination of its effect on vascular function of healthy individuals. Published articles on spray-dried FPH are generally aimed on studying of different properties of FPH using one-mode adjusted spray-drying just as an operation in the technological line. This gap should be filled by relative research devoted to the influence of spray-drying mode on the properties of FPH.

Freeze drying Freeze drying is a technique which utilizes the principle of moisture sublimation under lowered pressure. Because of that, the technique is often called vacuum freeze drying. Liquid FPH is frozen in a form of flat thin block at low temperatures (lower than $-35.0^{\circ} \mathrm{C}$ ). Then, the block of frozen FPH is transferred for drying into a vacuum chamber (Fig. 9) under low pressure (below 1.0 mbar). The energy for ice sublimation is provided through the shelves installed into the vacuum chamber. The pressure and temperature in the chamber are kept below the triple point of water; due to this, the sublimation of ice occurs in the frozen product, which forms fine porous structure of the dried layer. During the drying process, the water vapor crystallizes on the heat exchanger's surface. The temperature on the product's surface refers to the pressure in the drying chamber; it should be kept low enough to ensure only solid state of water at a given pressure (usually bellow - 56.0 C). The rate of moisture removal depends on thickness of frozen product and ice thickness on the heat exchanger's surface: increasing the product's thicknesses decreases the dehumidification rate significantly. Some part of the water is difficult to remove at low temperatures (primary drying). Thus, the drying temperature is increasing at the final stage of the drying process (secondary drying). 


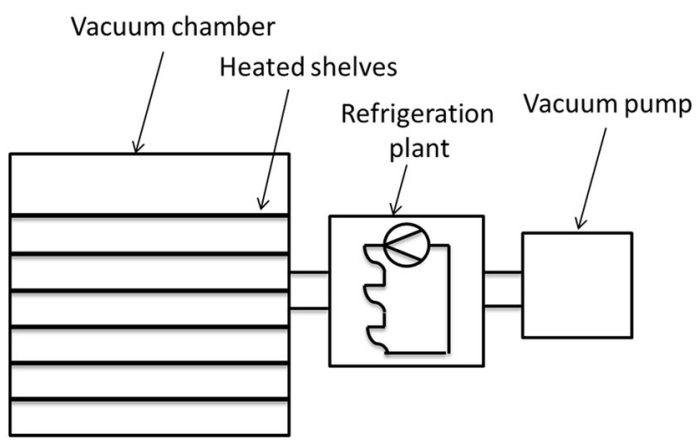

Fig. 9 Principal scheme of vacuum-freeze dryer

Freeze drying is a highly applicable method used for FPH drying at laboratory scale due to its simplicity and speed. A large number of authors have used freeze drying for the recovery of FPH in a number of researches, which studied different FPH purposes (Jenkelunas and Li-Chan, 2018; Noman et al. 2018; Halim et al. 2018) and many others. For example, the work of He et al. (2013) used freeze drying for the examination of functional properties of FPH. Elavarasan et al. (2016) used freeze drying in the evaluation of bioactive, clinical and structural properties of freeze-dried FPH from freshwater fish. Through a number of research work, freeze drying showed gentle treatment of the hydrolyzed mixture and a good protein recovery together with low moisture content in final dried FPH.

However, at large-scale production the cost and limited producing capacity of freeze-drying plays a negative role, where freeze drying is mostly used for the production of the highest quality FPH. When producing FPH for biochemical or medicine purposes, for example, as growing media for different microbiological cultures, freeze drying can be utilized at a certain extent.

Roller drum drying The principle of roller drum drying in the FPH production is to supply liquid FPH feed to the surface of horizontally mounted rotating hollow cylinder (single drum dryer) or two cylinders rotating towards each other (double drum dryer) or away from each other (twin drum dryer). The diameter of cylinders generally ranges from 0.5 to $6 \mathrm{~m}$, while the length alters between 1 and $6 \mathrm{~m}$ (Juming and Shen 2003). Thus, thin coating of FPH $(0.5-2 \mathrm{~mm})$ on the heated surface is created. In Fig. 10, a simple sketch of a typical double drum dryer is shown. The heated surface at the temperature generally up to $200{ }^{\circ} \mathrm{C}$ provides necessary latent heat to the liquid product to be dried. The temperature of the product rises up to the temperature of free water boiling during a few moments after coating the drum. Most moisture evaporates at a water boiling

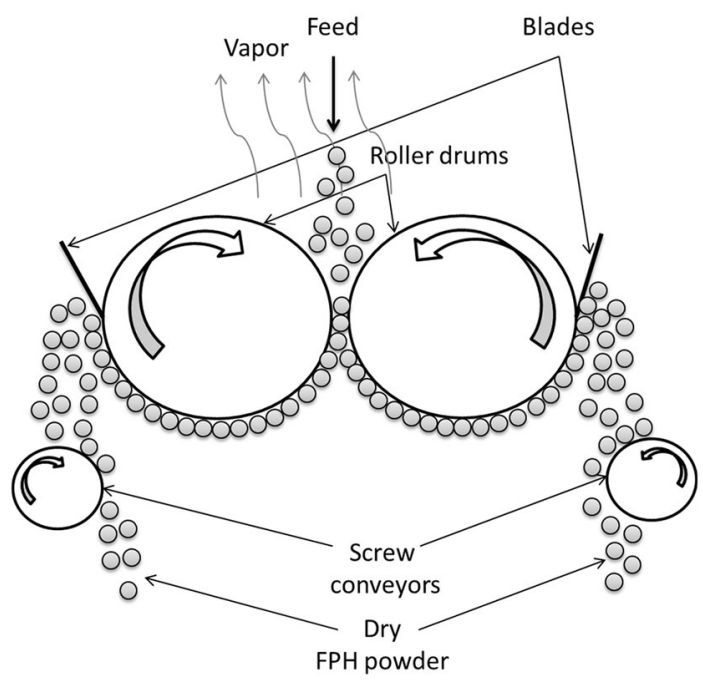

Fig. 10 Principal scheme of roller drum dryer 
temperature during the following constant drying rate period; the rest is removed when the temperature of the dried mass goes up to the boiling temperature of bounded water just before the scrapping the dried mass by scrapping blades.

Such properties as feed method and rate, heat supply rate, roll speed, and thickness of the product film play a key role in the control and manage the roller drum drying (Juming and Shen 2003).

Drum drying is not a popular methods applied to the research on FPH, probably, due to the relative complexity of operation at small scale. The search of the works, which applied drum drying to FPH, gave the research of Zhou et al. (2016). The authors applied drum drying to FPH from squid and scallop.

Energy aspects of FPH production

\section{Energy demands of main technological operations}

There is a lack of information concerning drying of hydrolysates and energy efficiency analysis. However, other liquid food products have similar thermo-physical properties and moisture content; thus, the related energy efficiency values can be used as a reference for the evaluation.

Main energy demanding processes of FPH manufacture are hydrolysation, concentration and drying steps. Drying at industrial scale is mostly utilized by spray dryers and, thus, their performance must be evaluated for making a conclusion on energy status of the operation. Moisture evaporation rate for most spray dryers is found in the range between 600 and 41,000 kg/h (Baker and McKenzie 2005). Some pilot models of spray dryers have specific energy consumption in the range between 3000 and $5500 \mathrm{~kJ} / \mathrm{kg}$ of evaporated water (AlMansour et al. 2011), but the real heat consumption by industrial models of spray dryers is much higher. The average energy consumption for industrial spray dryers is in the range between 4500 and $11500 \mathrm{~kJ} / \mathrm{kg}$ (Mujumdar 2007). The review, devoted to energy efficiency of spray dryers with respect to the industry, revealed the average energy consumption for food production as $4880 \mathrm{~kJ} / \mathrm{kg}$ of evaporated water in the case of multi-stage spray dryers (Baker and McKenzie 2005).

Meanwhile, for the other heat demanding processes of FPH manufacture, heating loads are far lower. For example, for enzymatic hydrolysis the main energy consumption can be split into 3 stages: heating of the raw material and water to hydrolysation temperature, maintenance at hydrolysation temperature and final heating to terminate the hydrolysis. There is a necessity to reach working temperatures in a short period of time. Thus, the high heating loads are suspected from heating devices for the first and third stage due to the high specific heat capacity of the mixture. One can assume the heat capacity of the mixture in the range between 3.6 and $3.9 \mathrm{~kJ} /(\mathrm{kg} * \mathrm{~K}$ ) (ASHRAE 1999) considering the ratio of fish to water as 1:1. Thus, simple calculations give the approximate heat consumption for enzymatic hydrolysis in the range of 583-175, 0.032-3.8 and 136-252 kJ/ $\mathrm{kg}$ for heating, hydrolysis procedure and termination of hydrolysis, respectively.

Concentration steps have higher heat consumption than for hydrolysis-around $5000 \mathrm{~kJ} / \mathrm{kg}$, but this step is an additional operation which may be added to prepare the mixture before the drying step and not an essential technological step. Moreover, it generally consumes much less energy than drying step of the FPH production.

Thus, the drying step of FPH production is the main energy consumer in the technological chain. Due to huge energy supply to the drying, energy saving in the drying process should become an important issue of FPH production. Energy effective solution provides not only huge economy savings, but also help to reduce the emission of the greenhouse effect gases, and, consequently, global warming (Mujumdar, 2007).

\section{Possible solutions for the improvement in energy efficiency of dehydration procedure for FPH}

Statistical data on convective dryers show that $20-60 \%$ of the supplied heat goes to moisture evaporation, $15-40 \%$ to heat losses with the exhaust air, $5-25 \%$ to product heating, $3-10 \%$ to heat losses through the walls and 5-20\% to other losses (Danilov and Leontchik 1986; Mujumdar 2007). Thus, considering the main heat expenses, the efforts referring energy savings should be applied mainly to energy reduction during moisture evaporation and product heating; to recovery of the heat from exhaust air; and to decrease of the heat losses to the atmosphere. The following proposals referring the main heat expenses may help decreasing energy costs of FPH production and increasing its efficiency: 
- Moisture evaporation.

Heat supply for the evaporation of moisture can be reduced by

- Product concentration before drying: in this case, solid content increases up to a certain value positively influence the drying efficiency (Masters 1991).

- Increase of the drying temperature or, consequently, the difference between the drying agent (surface) and the product: this would increase the drying rate, but also may influence badly on the quality of sensitive materials.

- Product distribution: this property contributes to uniform mass- and heat transfer when the product is distributed uniformly and in a properly adjusted amount into or over a certain volume of a spray drier or drum and vacuum-freeze driers, respectively.

- Other methods suitable for the operation of spray driers:

1. Multistage drying can be used as a solution for spray driers when the introduction of an additional unit into the system may give a positive result. In such a unit, the product is dried during the constant rate period, which is governed by internal moisture diffusion and, where moisture takes longer time to get out the product. An example of such a system is a fluidized bed (stationary or vibrated) installed at the lower part of a spray drier. This method with a proper operation can save up to around $35 \%$ of consumed energy (Mujumdar 2007).

2. Humidity control: for hygroscopic materials, air relative humidity of a drying agent can be a controlling factor. In this case, dehumidification of the drying agent can be considered. However, for the majority of application, air relative humidity at the entrance of spray drier is below the level that can inhibit completion of the drying process (Masters 1991).

- Recover of heat from exhaust air.

This part includes the recovery of the heat from drying air by the use of heat pumps or heat exchangers. The recovered heat can be used on different technological needs of the production.

- Product heating.

The preheating of the product can reduce energy consumption on product heating during drying. In this case, the viscosity of the product can be reduced which is desirable as for the better atomization of liquids in spray driers and for uniform distribution of the product on the surface of a drum drier and on the plates of a vacuum-freeze drier.

- Heat losses through the walls of equipment.

A proper insulation should be considered in order to decrease heat losses to the atmosphere through the walls of equipment. It can considerably reduce the energy consumption of the equipment with low investment costs and minimum labor efforts.

\section{Conclusions}

This paper gives a broad overview on the production of FPH from the step of raw material to the final drying of the hydrolysated product. The matters of type and availability of fish by-products were considered regarding the worldwide production. The stage of hydrolysis was evaluated according to the efficiency and safety. Enzymatic hydrolysis was chosen as the most promising solutions so far. Possible pre-treatment steps before the drying were considered in order to evaluate their efficiency in the decreasing of energy costs for the main drying step. Drying techniques used for FPH were highlighted together with their energy consumption and possible solutions for the effective energy management. Summarizing, the production of FPH ought to be adjusted so as to switch between available raw materials regarding its availability; the hydrolysation step can be carried out by enzymatic hydrolysis using the commercial mixture of Papain and Bromelain as a hydrolyzing agent; purification should be accomplished essentially by techniques which answer the producers' 
expectations to the final quality; the step of concentration may be added to the technological scheme, but not essentially; the drying step is still provided more efficiently by spray drying, but aforesaid improvements can be introduced to the existing installations.

Acknowledgements Thanks to the Department of Energy and Process Engineering and the Industrial Process Technology Group of NTNU for their valuable support and cooperation.

Open Access This article is distributed under the terms of the Creative Commons Attribution 4.0 International License (http:// creativecommons.org/licenses/by/4.0/), which permits unrestricted use, distribution, and reproduction in any medium, provided you give appropriate credit to the original author(s) and the source, provide a link to the Creative Commons license, and indicate if changes were made.

\section{References}

Abdelhedi O, Nasri R, Mora L, Jridi M, Toldrá F, Nasri M (2018) In silico analysis and molecular docking study of angiotensin I-converting enzyme inhibitory peptides from smooth-hound viscera protein hydrolysates fractionated by ultrafiltration. Food Chem 239:453-463. https://doi.org/10.1016/j.foodchem.2017.06.112

Abdul-Hamid A, Bakar J, Bee GH (2002) Nutritional quality of spray dried protein hydrolysate from Black Tilapia (Oreochromis mossambicus). Food Chem 78(1):69-74. https://doi.org/10.1016/S0308-8146(01)00380-6

Abejón R, Abejón A, Belleville MP, Sánchez-Marcano J, Garea A, Irabien Á (2016) Multiobjective Optimization of Membrane Networks for Fractionation of Protein Hydrolysate from Fish By-Products. In: Kravanja Z, Bogataj M (eds) Computer Aided Chemical Engineering. Elsevier, Amsterdam

Abejón R, Belleville MP, Sanchez-Marcano J, Garea A, Irabien A (2018) Optimal design of industrial scale continuous process for fractionation by membrane technologies of protein hydrolysate derived from fish wastes. Sep Purif Technol 197:137-146. https://doi.org/10.1016/j.seppur.2017.12.057

Aliani M, Eskin MNA (2017) Bitterness: perception, chemistry and food processing. Wiley, New Jersey

Al-Mansour HE, Al-Busairi BH, Baker CGJ (2011) Energy consumption of a pilot-scale spray dryer. Dry Technol 29(16):1901-1910. https://doi.org/10.1080/07373937.2011.595563

Alvares TS, Conte-Junior CA, Pierucci AP, de Oliveira GV, Cordeiro EM (2018) Acute effect of fish protein hydrolysate supplementation on vascular function in healthy individuals. Journal of Functional Foods 46:250-255. https://doi.org/10. 1016/j.jff.2018.04.066

ASHRAE (1999) ASHRAE handbook. American Society of Heating, Refrigerating and Air Conditioning Engineers, Atlanta

Aubes-Dufau I, Capdevielle J, Seris JL, Combes D (1995) Bitter peptide from hemoglobin hydrolysate: isolation and characterization. FEBS Lett 364(2):115-119

Baker CGJ, McKenzie KA (2005) Energy consumption of industrial spray dryers. Dryi Technol 23(1-2):365-386. https://doi.org/ 10.1081/DRT-200047665

Bikov VP, Ionas GP, Golovkova GN, Didenko AP, Akulin VN, Perova LI, Odincov AB, Konstantinova LL, Dvinin UF, Christoferzen GS, Borisova LP (1998) Book of chemical content and technological properties of seawater and oceanic fishes. VNIRO Press, Moscow

Blenford DE (1994) Protein hyddrolysates: functionalities and uses in nutritional products. Int Food Ingr 3:45-49

Bourseau P, Vandanjon L, Jaouen P, Chaplain-Derouiniot M, Massé A, Guérard F, Chabeaud A, Fouchereau-Pérond M, Le Gal Y, Ravallec-Plé L, Bergé J-P, Picot L, Piot J-M, Batista I, Thorkelsson G, Delannoy C, Jakobsen G, Johansson I (2009) Fractionation of fish protein hydrolysates by ultrafiltration and nanofiltration: impact on peptidic populations. Desalination 244(1):303-320. https://doi.org/10.1016/j.desal.2008.05.026

Chae HJ, In MJ, Kim MH (1998) Process development for the enzymatic hydrolysis of food protein: effects of pre-treatment and post-treatments on degree of hydrolysis and other product characteristics. Biotechnol Bioproc E 3(1):35-39. https://doi.org/ 10.1007/BF02932481

Chakraborty PK, Madhavan P (1977) A pilot scale set up for the manufacture of fish hydrolysate. Fish Technol 14(2):159

Chalamaiah M, Dinesh Kumar B, Hemalatha R, Jyothirmayi T (2012) Fish protein hydrolysates: proximate composition, amino acid composition, antioxidant activities and applications: A review. Food Chem 135(4):3020-3038. https://doi.org/10.1016/j. foodchem.2012.06.100

Cui H (1996) The influence of degree of hydrolysis on the structural and functional properties of fish protein peptic hydrolysates. Masters thesis. University of Washington, Seattle

Damodaran S, Parkin KL, Fennema OR (2008) Fennema's Food Chemistry. CRC Press, Boca Raton

Danilov OI, Leontchik BI (1986) Energy Economic in Thermal Drying. Energoatomizdat, Moscow

Di Pasquale MG (2008) Amino acids and proteins for the athlete: the anabolic edge. CRC Press, Boca Raton

Elavarasan K, Shamasundar BA, Badii F, Howell N (2016) Angiotensin I-converting enzyme (ACE) inhibitory activity and structural properties of oven- and freeze-dried protein hydrolysate from fresh water fish (Cirrhinus mrigala). Food Chem 206:210-216. https://doi.org/10.1016/j.foodchem.2016.03.047

European Comission (2012) https://ec.europa.eu/fisheries/cfp/aquaculture/species_en. Accessed 26 Sept 2018

FAO (2007) http://www.fao.org/3/a-a1394e.pdf. Accessed 26 Sept 2018

FAO (2016) http://www.fao.org/3/a-i5555e.pdf. Accessed 26 Sept 2018 
FAO (2017) http://www.fao.org/fi/static-media/MeetingDocuments/WorkshopAMR17/presentations/22.pdf. Accessed 26 Sept 2018

GEA (2018) http://www.gea.com/en/products/falling-film-evaporator.jsp Accessed 26 Sept 2018

GEA Process Engineering A/S (2016) GEA Niro spray drying. Small-scale solutions for R\&D and production. GEA Process Engineering A/S, Danmark

Gonzalez-Tello P, Camacho F, Jurado E, Paez MP, Guadix EM (1994) Enzymatic hydrolysis of whey proteins: i. Kinetic models. Biotechnol Bioeng 44(4):523-528. https://doi.org/10.1002/bit.260440415

Halim NRA, Azlan A, Yusof HM, Sarbon NM (2018) Antioxidant and anticancer activities of enzymatic eel (monopterus sp) protein hydrolysate as influenced by different molecular weight. Biocatal Agric Biotechnol 16:10-16. https://doi.org/10. 1016/j.bcab.2018.06.006

He S, Franco C, Zhang W (2013) Functions, applications and production of protein hydrolysates from fish processing co-products (FPCP). Food Res Int 50(1):289-297. https://doi.org/10.1016/j.foodres.2012.10.031

Himonides AT, Taylor AKD, Morris AJ (2011) Enzymatic Hydrolysis of Fish Frames Using Pilot Plant Scale Systems. Food Nutr Sci 2:586-593

Hoeling A, Volkov V (2015) Proteins from by-products - innovative components in sustainable industrial production. Proceedings of KGTU 38:83-92

Huang S, Vignolles ML, Chen XD, Le LY, Jan G, Schuck P, Jeantet R (2017) Spray drying of probiotics and other food-grade bacteria: a review. Trends Food Sci Tech 63:1-17. https://doi.org/10.1016/j.tifs.2017.02.007

Jaswal AS (1990) Amino Acid Hydrolysate from Crab Processing Waste. J Food Sci 55(2):379-380. https://doi.org/10.1111/j. 1365-2621.1990.tb06768.x

Jenkelunas PJ, Li-Chan ECY (2018) Production and assessment of Pacific hake (Merluccius productus) hydrolysates as cryoprotectants for frozen fish mince. Food Chem 239:535-543. https://doi.org/10.1016/j.foodchem.2017.06.148

John TG (1993) Non-bitter protein hydrolyzates. US Patent 5266685, USA

Juming THF, Shen GQ (2003) Drum Drying. In: Encyclopedia of agricultural, food, and biological engineering. Marcel Dekker, Inc., New York, pp 211-214. https://doi.org/10.1081/e-eafe 120007091

Kinsella JE, Melachouris N (1976) Functional properties of proteins in foods: a survey. Crit Rev Food Sci 7(3):219-280. https:// doi.org/10.1080/10408397609527208

Kristinsson HG (1998) Reaction kinetics, biochemical and functional properties of salmon muscle proteins hydrolyzed by different alkaline proteases. Masters thesis. University of Washington, Seattle

Kristinsson HG, Rasco BA (2000) Fish Protein Hydrolysates: production, Biochemical, and Functional Properties. Critical Rev Food Sci 40(1):43-81. https://doi.org/10.1080/10408690091189266

Kuehler CA, Stine CM (1974) Effect of enzymatic hydrolysis on some functional properties of whey protein. J Food Sci 39(2):379-382. https://doi.org/10.1111/j.1365-2621.1974.tb02899.x

Lahl WJ, Braun SD (1994) Enzymatic production of protein hydrolysates for food use. Food Sci 48:68-71

Linder M, Fanni J, Parmentier M, Sergent M, Phan-Tan-Luu R (1995) Protein recovery from veal bones by enzymatic hydrolysis. J Food Sci 60(5):949-952. https://doi.org/10.1111/j.1365-2621.1995.tb06268.x

Loffler A (1986) Proteolytic enzymes: sources and applications. Food Technol-Chicago 40(1):63

Loosen P, Bressollier P, Julien R, Pejoan CH, Verneuil BG (1994) Method for preparing an enzymatic hydrolysate. United States Patent 5356637

Manninen AH (2004) Protein hydrolysates in sports and exercise: a brief review. J Sport Sci Med 3(2):60-63

Masters K (1991) Spray drying handbook, 5th edn. Longman Scientific \& Technical, New York

Microlab Scientific (2018) http://www.microlabscientific.com/Membrane-Filter.html. Accessed 26 Sept 2018

Mine Engineer Product Manual (2009) http://www.mine-engineer.com/mining/plate.htm Accessed 26 Sept 2018

Morales-Medina R, Tamm F, Guadix AM, Guadix EM, Drusch S (2016) Functional and antioxidant properties of hydrolysates of sardine (S. pilchardus) and horse mackerel (T. mediterraneus) for the microencapsulation of fish oil by spray-drying. Food Chem 194:1208-1216. https://doi.org/10.1016/j.foodchem.2015.08.122

Mujumdar AS (2007) Principles, classification and selection of dryers. In: Mujumdar AS (ed) Handbook of industrial drying. CRC Press, Boca Raton

Noman A, Xu Y, Al-Bukhaiti WQ, Abed SM, Ali AH, Ramadhan AH, Xia W (2018) Influence of enzymatic hydrolysis conditions on the degree of hydrolysis and functional properties of protein hydrolysate obtained from Chinese sturgeon (Acipenser sinensis) by using papain enzyme. Process Biochem 67:19-28. https://doi.org/10.1016/j.procbio.2018.01.009

NPTEL (2013) National programme on technology enhanced learning. Module 3: design of evaporator. Lecture 1: introduction and evaporator classifications. Government of India, Ministry of Human resource development, India

Pasupuleti VK, Braun S (2010) State of the art manufacturing of protein hydrolysates. In: Pasupuleti VK, Demain AL (eds) Protein hydrolysates in biotechnology. Springer, Dordrecht, pp 11-32. https://doi.org/10.1007/978-1-4020-6674-0_2

Quaglia GB, Orban E (1987) Enzymic solubilisation of proteins of sardine (sardina pilchardus) by commercial proteases. J Sci Food Agr 38(3):263-269. https://doi.org/10.1002/jsfa.2740380310

Quaglia GB, Orban E (1990) Influence of enzymatic hydrolysis on structure and emulsifying properties of sardine (sardina pilchardus) protein hydrolysates. J Food Sci 55(6):1571-1573. https://doi.org/10.1111/j.1365-2621.1990.tb03571.x

Rebeca BD, Peña-Vera MT, DiAz-Castañeda M (1991) Production of fish protein hydrolysates with bacterial proteases; yield and nutritional value. J Food Sci 56(2):309-314. https://doi.org/10.1111/j.1365-2621.1991.tb05268.x

Richardsen R, Nystøyl R, Marthinussen A (2015) Analyse marint resteråstoff, 2015. Rapport. Analyse av tilgang og anvendelse for marint restråstoff I Norge. SINTEF Fiskeri og Havbryk, Trondheim

Roslan J, Mustapa Kamal SM, Yunos KF, Abdullah N (2018) Evaluation on performance of dead-end ultrafiltration membrane in fractionating tilapia by-product protein hydrolysate. Sep Purif Technol 195:21-29. https://doi.org/10.1016/j.seppur.2017.11. 020 
Saidi S, Deratani A, Belleville M-P, Amar RB (2014) Production and fractionation of tuna by-product protein hydrolysate by ultrafiltration and nanofiltration: impact on interesting peptides fractions and nutritional properties. Food Res Int 65:453-461. https://doi.org/10.1016/j.foodres.2014.04.026

Sarmadi BH, Ismail A (2010) Antioxidative peptides from food proteins: a review. Peptides 31(10):1949-1956. https://doi.org/10. 1016/j.peptides.2010.06.020

SeaFoodSource (2016) https://www.seafoodsource.com/news/supply-trade/entrepreneurs-getting-creative-with-seafood-bypro ducts. Accessed 26 Sept 2018

Sikorski ZE, Naczk M (1981) Modification of technological properties of fish protein concentrates. Crit Rev Food Sci 14(3):201-230. https://doi.org/10.1080/10408398109527305

Silvestre MPC, Vieira CR, Silva MR, Carreira RL, Silva VDM, Morais HA (2009) Protein extraction and preparation of protein hydrolysates from rice with low phenylalanine content. Asian J Sci Res 2:146-154

Skanderby M (1994) Protein hydrolysates: their functionality and applications. Food Technol Int 10:141-144

Slizyte R, Grimsmo L, Storrø I (2010) Raport. Processering av biråstoff fra sild til olje og proteinhydrolysat. Laboratoriefors $ø \mathrm{k}$ med ulike proteaser og pilotfors $ø$ k med ultrafersk råstoff. Rapport. SINTEF Fiskeri og Havbryk, Trondheim

Spinelli J, Koury B, Miller R (1972) Approaches to the utilization of fish for the praparation of protein isolates. J Food Sci 37(4):599-603. https://doi.org/10.1111/j.1365-2621.1972.tb02702.x

Suwal S, Ketnawa S, Liceaga AM, Huang J-Y (2018) Electro-membrane fractionation of antioxidant peptides from protein hydrolysates of rainbow trout (Oncorhynchus mykiss) byproducts. Innov Food Sci Emerg 45:122-131. https://doi.org/10. 1016/j.ifset.2017.08.016

Tannenbaum SR, Ahern M, Bates RP (1970a) Solubilization of fish protein concentrate. I. An alkaline process. Food TechnolChicago 24:604-606

Tannenbaum SR, Ahern M, Bates RP (1970b) Solubilization of fish protein concentrate. II. Utilization of the alkaline-process product. Food Technol-Chicago 24:607

Vandanjon L, Grignon M, Courois E, Bourseau P, Jaouen P (2009) Fractionating white fish fillet hydrolysates by ultrafiltration and nanofiltration. J Food Eng 95(1):36-44. https://doi.org/10.1016/j.jfoodeng.2009.04.007

Webster JD, Ledward DA, Lawrie RA (1982) Protein hydrolysates from meat industry by-products. Meat Sci 7(2):147-157. https://doi.org/10.1016/0309-1740(82)90080-8

Wisniewski R (2015) Spray drying technology review. Paper presented at the 45th International Conference on Environmental Systems Bellevue, 12-16 July 2015. Washington

Ytrestøyl T, Aas TS, Åsgård T (2014). Recourse utilization of Norwegian salmon farming in 2012 and 2013. Report 36/2014. Nofima, Troms $\varnothing$

Zhou Y, Thirumurugan R, Wang Q, Lee CM, Davis DA (2016) Use of dry hydrolysate from squid and scallop product supplement in plant based practical diets for Pacific white shrimp Litopenaeus vannamei. Aquaculture 465:53-59. https://doi.org/10. 1016/j.aquaculture.2016.08.028

Zhu Z, Wu Q, Di X, Li S, Barba FJ, Koubaa M, Roohinejad S, Xiong X, He J (2017) Multistage recovery process of seaweed pigments: investigation of ultrasound assisted extraction and ultra-filtration performances. Food Bioprod Process 104:40-47. https://doi.org/10.1016/j.fbp.2017.04.008

\section{Publisher's Note}

Springer Nature remains neutral with regard to jurisdictional claims in published maps and institutional affiliations. 